\title{
EVALUATION OF RELEASE Coccinella undecimpunctata L. FOR CONTROLLING CERTAIN PIERCING-SUCKING INSECTS INFESTING COTTON FIELDS AT MANZALA DISTRICT, DAKHLIA GOVERNORATE
}

\author{
Ghanim, A. A.*; A. H. Abdel-Salam*; S. A. Emara** and \\ R. M. Radwan ** \\ * Economic Entomology Dept., Fac. Agric., Mansoura Univ., Egypt. \\ ** Plant Protection Res. Inst., Agric. Res. Center, Dokki, Giza, Egypt.
}

\begin{abstract}
Field experiments were carried out in cotton felids at Manzala district, Dakhlia Governorate during two successively seasons 2008 and 2009 to evaluate the release of $C$. undecimpunctata for controlling certain piercing-sucking insects infesting cotton fields. The obtained results in untreated area revealed that were four peaks for the piercing-sucking insects in cotton fields during the two seasons of study at Manzala district. The predator prey ratio in this area was 4.56, in 2008 season, while it was 4.64 in 2009 season at the beginning of study, then these ratios increased gradually and reached their maximum 1: 19.6 in 2008 and 1: 16.78 in 2009. In the treated area with $C$. undecimpuctata the ratio exceeded the critical ratio $(1: 10)$ in the following dates: the third week of June, in third week of July, in the second week of August and in the end of August during 2008 season. The number of this coccinellid predator needed to justify the ratio were 2500, 2000, 2000 and 2500 individuals, in the four dates of releasing respectively. While the predator prey ratio exceeded the critical ratio $(1: 10)$ in the following dates: in the second week of June, in the first week of July, in the first week of August and the end of August during 2009 season. The number needed from this predator to justify the ratio were two thousands individuals in the four dates of releasing respectively. The results showed clearly the possibility of using C. undecimpunctata as a biological control agent against the piercing-sucking insect in cotton crop.

Keywords: Coccinella undecimpunctata - piercing-sucking insect - cotton crop release - Biological control.
\end{abstract}

\section{INTRODUCTION}

Cotton crop able to infestation by different piercing-sucking insects species during the cotton growing season causing a serious damage to yield quality and quantity.

Theory and practical of biological control suggest that generalist predators can be effective control agents. Field studies show that generalist predators can reduce pest numbers by a significant degree and in some cases reduce or prevent crop damage. This evidence is mainly from semifield condition (field cage) and providing that predator: prey ratios and the timing of releases are optimized Symondson et al. (2002). Predatory insect species are frequently abundant in annual crops including cotton crop and have been identified as important in suppression populations of damaging insects Rosenheim et al. (1995). Several methods have been used to measure the effect of some coccinellids on certain insect pests populations. Detaild studies on the role of $C$. undecimpunctata against several insect 
Ghanim, A. A. et al.

pests have been studied extensively, Hodek et al. (1972); Shands et al. (1972); Wetzel et al. (1981); Ghanim and El-Adl (1987) ; Eraky and Nasser (1993) ; Abdel-Salam (1995) ; Ragab et al. (2002); Abdel-Salam et al. (2005) and Mohamed Nadia et al. (2008) studied the effect of release of $C$. undecimpunctata and $C$. carnea at different predator: prey ratios to control the cotton aphid, A. gossypii, on tomato plants under field cage conditions.

Therefore, the aim of the current investigation to evaluate the effect of release $C$. undecimpunctata for controlling certain piercing-sucking insects infesting cotton fields at Manzala district, Dakhlia Governorate

\section{MATERIALS AND METHODS}

Field experiments were carried out in the cotton felids at Manzala district, Dakhlia Governorate during two successively seasons 2008 and 2009 to evaluate the effect of release $C$. undecimpunctata for controlling certain piercing-sucking insects infesting cotton fields. One feddan was chosen for experiments and Giza 85 was the Varity of cotton cultivated during the two seasons of study. Three treatments were conducted treated with $C$. undecimpunctata; insecticides and control (untreated area). The method which was used in surveying the piercing-sucking insects and their predatory insects in cotton fields were yellow sticky traps and direct counting. Yellow paper cards $(20 \times 20 \mathrm{~cm})$ coated with sticky material was hanged on wedge at nearly the similar high of the plant. Five traps were distributed, in the area of study as follows: one was put in each corner in addition to another one in the center of area. The traps were changed weekly. The caught insect pests and the predatory insects were identified, and then recorded.

Field use Coccinella undecimpunctata to control certain cotton insects pests in the fields. In the treated area with $C$. undecimpunctata the ratio exceeded the critical ratio (1:10) in the following dates: the third week of June, in second of July, in the second week of August and the end of August during 2008 season. The number of this coccinellid predator needed to justify the ratio were $2500,2000,2000$ and 2500 individuals, in the four dates of releasing respectively. While the predator prey ratio exceeded the critical ratio $(1: 10)$ in the following dates: the second week of June, the first week of July, the first week of August and the end of August during 2009 season. The number needed from this predator to justify the ratio were two thousands individuals in the four dates of releasing respectively

To estimate the predator-prey ratio on the cotton crop tested 20 plants in open field were chosen randomly for this purpose. The total number of injurious and predatory insects on these plants was counted by direct counting method. The average number per plants and total number of plants were calculated. Consequently the expected number of piercing-sucking pests and predatory insects in cotton field could be estimated by multiplying the number of insects per plant. The expected calculated predator-prey ratios were obtained from the formula:

Total number of calculated piercing-sucking insects/ total number of calculated predatory insects. 
If the calculated predator / prey ratios exceeded 1: 10 (the critical ratios), $C$. undecimpunctata were released by the numbers exactly needed to maintain the critical ratios.

\section{RESULTS AND DISCUSSION}

\section{Using Coccinella undecimpunctata for controlling certain piercing- sucking insects in cotton field.}

As previously mentioned in the introduction of this work, predator $C$. undecimpunctata which reared naturally, have been used and evaluated in controlling percing-sucking insects attacking cotton crop.

As the predator prey ratio is the main value explaining the relation among the piercing-sucking and predatory insects, so when this ratio was under 1: 10 (the critical value), the predatory insects can play an effective role in controlling the abundance of piercing-sucking insects and could keep their numbers under the economic injury level, and vise versa if this ratio was higher than the previously mentioned ratio. Therefore this criteria was used in this study for detecting the proper time for introducing the predators (which reared naturally) into the fields.

Figures ( $1 \mathrm{~A}$ and $\mathrm{B})$ show the total of weekly catch for insect pests and their beneficial insects in untreated cotton area during 2008 season at Manzala district. It can be noted from these Figures that the weekly number of these pests have four peaks, in the mid of June, in the second week of Jule, in the second week of August and in the first week of September respectively, then decreased sharply and reached its lowest number at the third week of September.

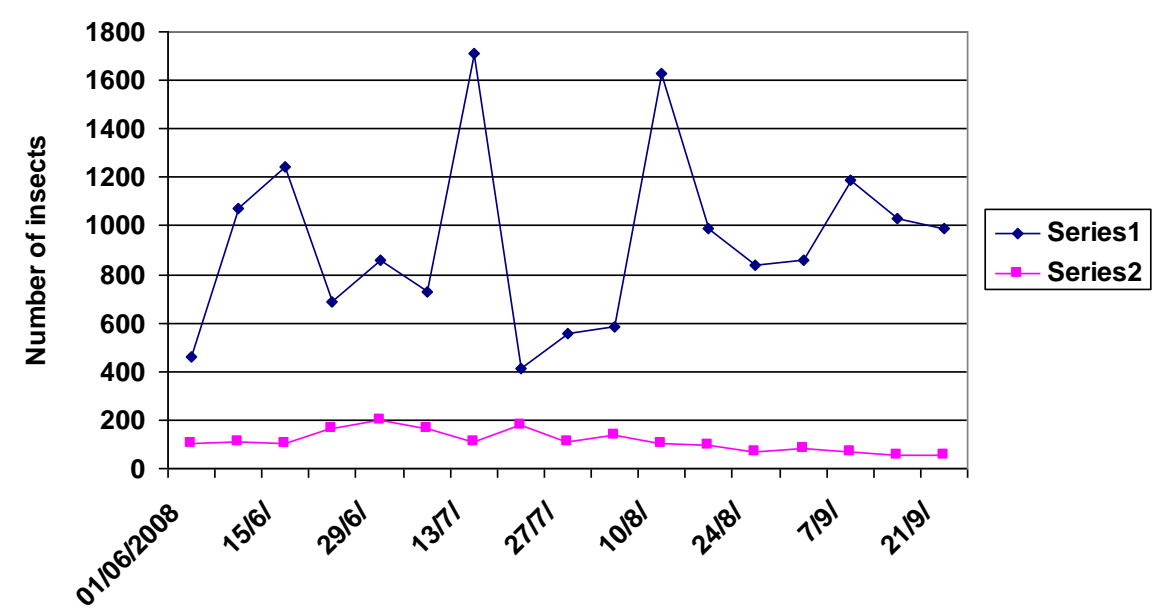

Sampling dates

Figure (1-A): Weekly numbers of certain piercing-sucking insects and their associated predatory insects in untreated cotton area (control) at Manzala district during 2008 season. 
Ghanim, A. A. et al.

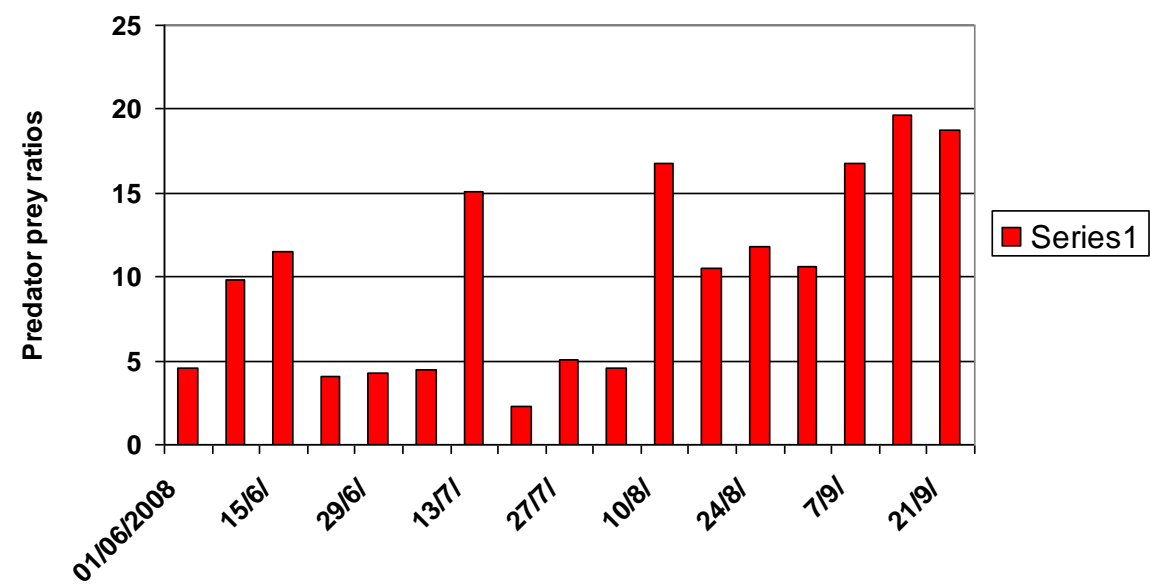

Sampling dates

Figure (1-B): Calculated predator prey ratios in untreated cotton area (control) at Manzala district during 2008 season.

Also it can seen in Figure (1, B) the calculated predator prey ratio in untreated cotton area (without releasing the coccinellid predator or insecticides) during the same season this ratio was 1: 4.56 at the beginning of study, then the ratio fasted gradually and reached its maximum 19.06 by the second week of September. Afterwards this ratio began narrowed till the end of the cotton season. That may be refer to the naturally increase of the beneficial insects number due to the suitability of the environmental conditions, etc availability of hosts and preys needed for the natural beneficial insects; less competition, and suitable prevailing weather condition.

Figures (2 A and B) show the results of using predator $C$. undecimpunctata aiming to control the piercing-sucking insects in cotton during 2008 season.

It can be noted from this Figure that the predator prey ratio was exceeded 1:10 (the critical ratio) in the third week of June, in the third week of July, in the second week of August and the end of August. The numbers needed from the reared predator to justify the ratio were 2500, 2000, 2000 and 2500 individuals in the four dates release, respectively. The results in this figure indicated that the weekly total number of piercing-sucking insects were lower than that in the untreated area, that is certain due to the effective role of the released the coccinellid predator in checking the piercing-sucking insects as long as ratio of their abundance was within the critical ratio $1: 10$. 


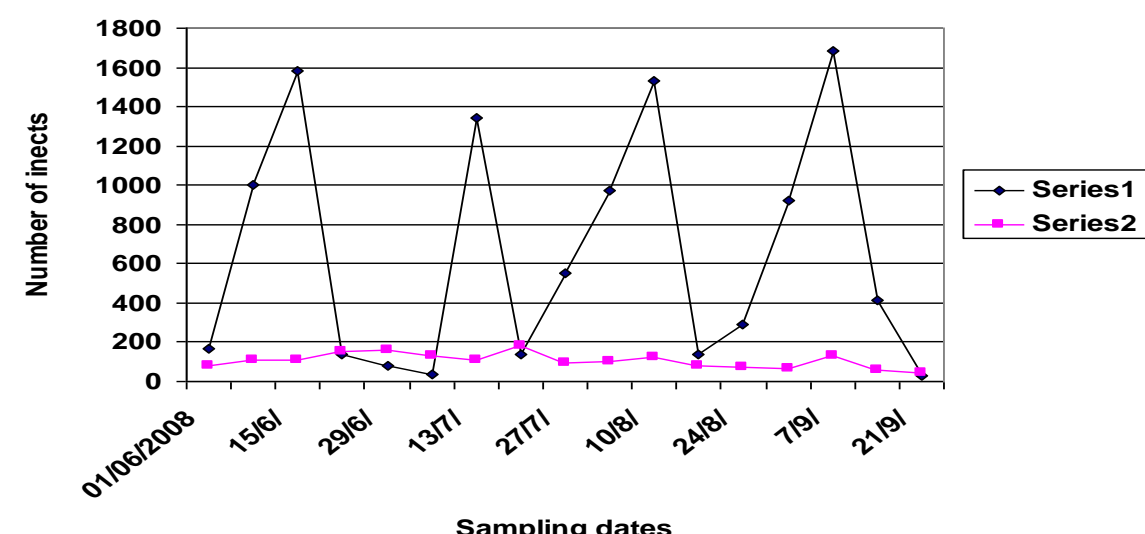

Figure (2-A): Weekly numbers of certain piercing-sucking insects and their associated predatory insects in treated cotton area with C. undecimpunctata at Manzala district during 2008 season.

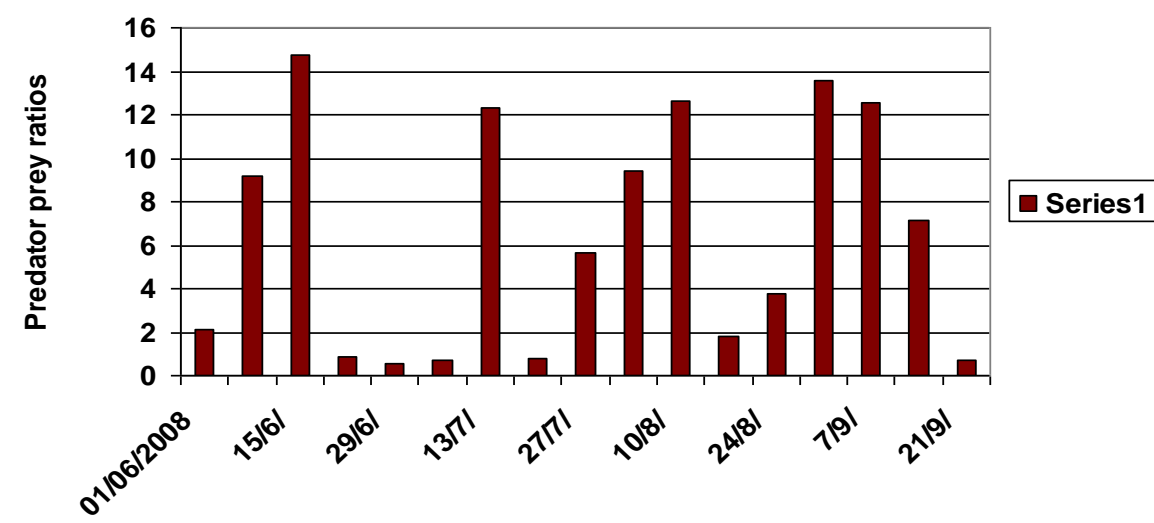

Sampling dates

Figure (2-B): Calculated predator prey ratios in treated cotton area with C. undecimpunctata at Manzala district during 2008 season.

Figures ( $3 A$ and $B$ ) show the results of using insecticides aiming to control the injurious insect in cotton during 2008 season. It can be noted from this Figure that the predator prey ratio was exceeded 1:10 (the critical ratio) in the third week of June, in the third week of July, in the second week of August and in the first week of September. The results in this figure indicated that the weekly total number of piercing-sucking insects were lower than that in the untreated area, that is due to the effective role of the insecticides in checking the piercing-sucking insects as long as ratio of their abundance was within the critical ratio $1: 10$. 
Ghanim, A. A. et al.

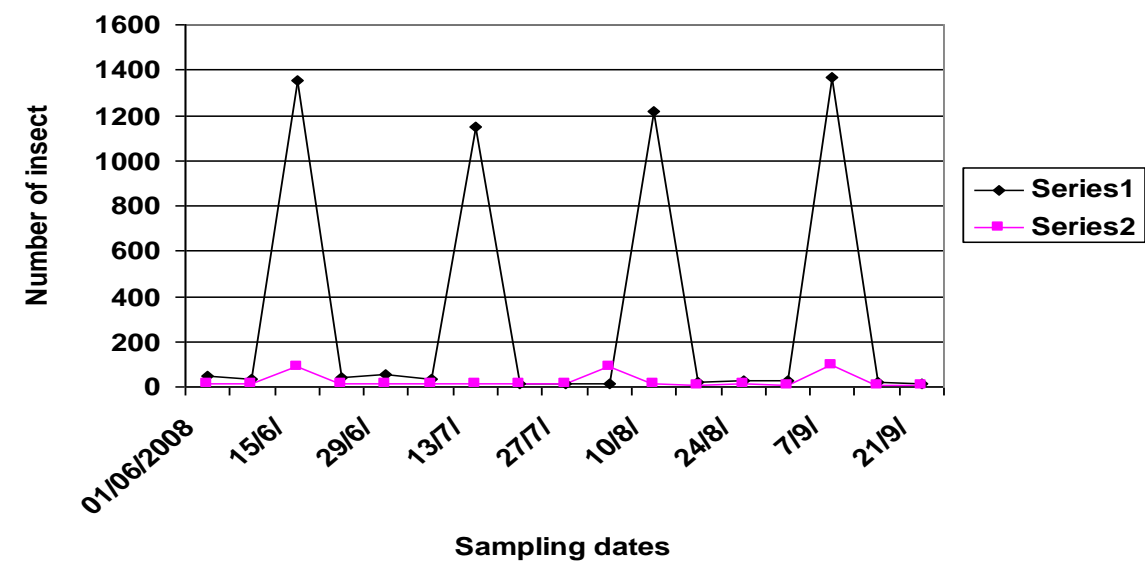

Figure (3-A): Weekly numbers of certain piercing-sucking insects and their associated predatory insects in treated cotton area with insecticides at Manzala district during 2008 season.

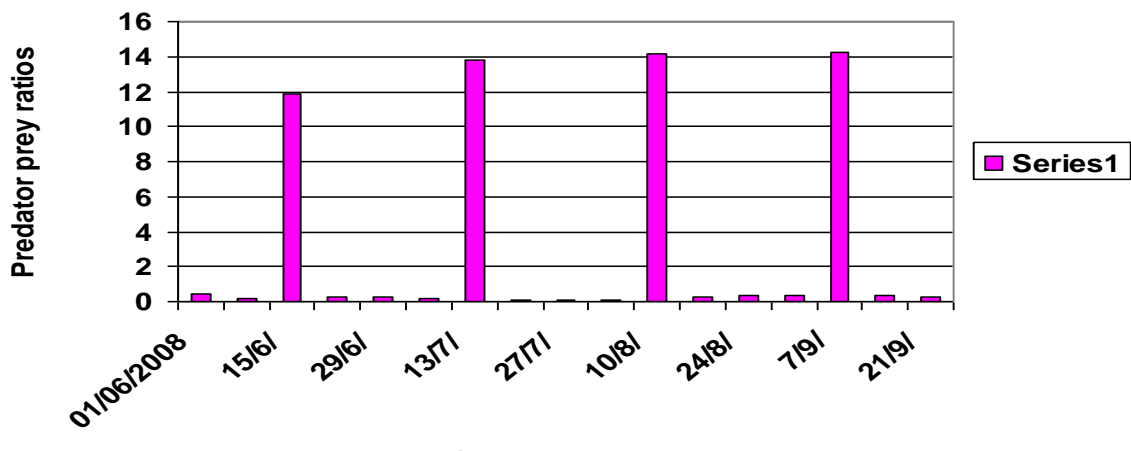

Sampling dates

Figure (3-B): Calculated predator prey ratios in treated cotton area with insecticides at Manzala district during 2008 season.

Figures (4 A and B) show the total of weekly catch for insect pests and their predatory insects in untreated cotton area of study during 2009 season at Manzala district. It can be noted from this Figure that the weekly number of these pests have four peaks, in the second week of June, in the first week of July, in the first week of August and in the end of August respectively, then decreased sharply and reached its lowest number at third week of September. Also it can seen in Figure $(4, \mathrm{~B})$ the calculated predator prey ratio in untreated cotton area (without releasing the coccinellid predator or insecticide) during the same season this ratio was 1: 9.04 at the beginning of study, then the ratio fasted gradually and reached its maximum 16.78 by the first week of August. Afterwards this ratio began narrowed till the end of the cotton season. 


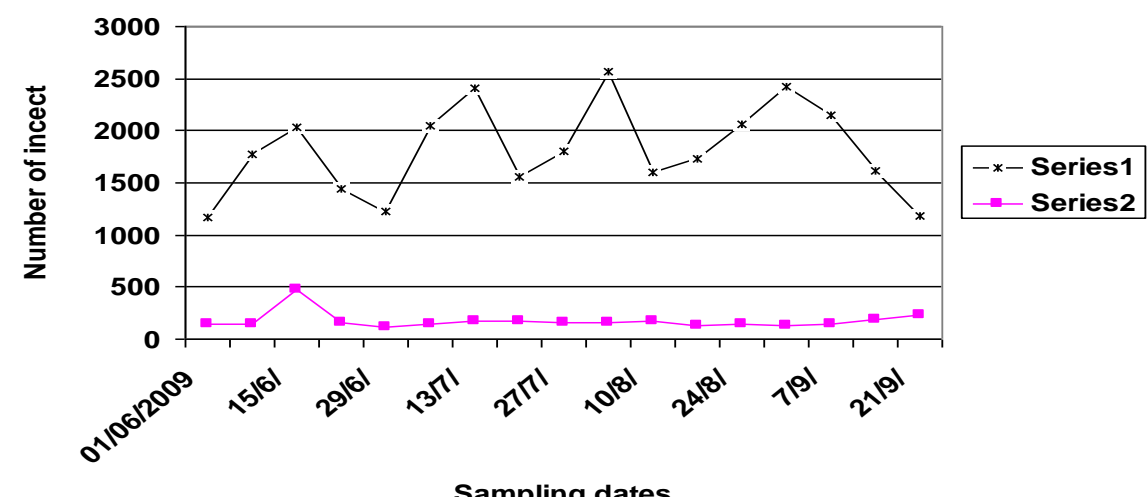

Figure (4-A): Weekly numbers of certain piercing-sucking insects and their associated predatory insects in untreated cotton area (control) at Manzala district during 2009 season.

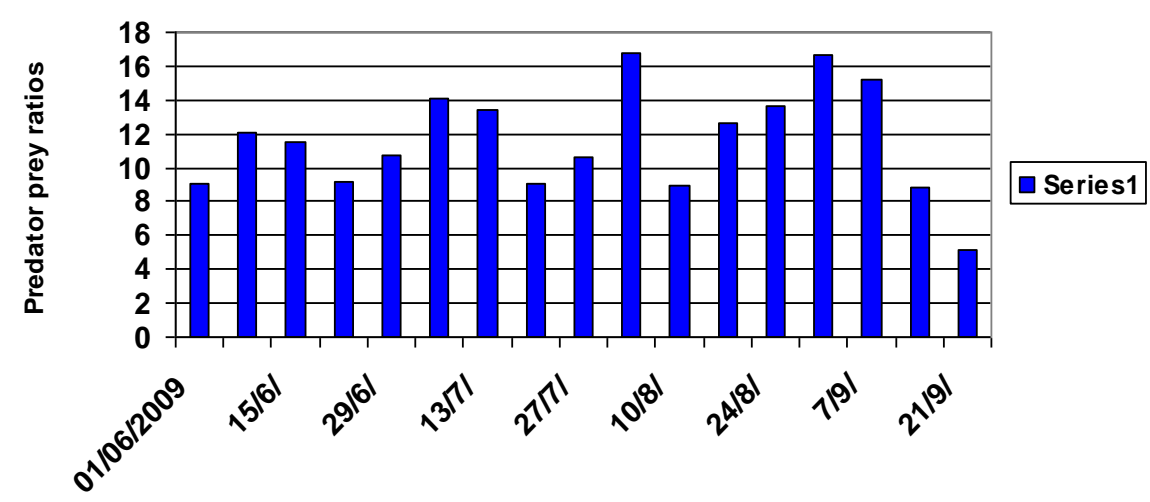

Sampling dates

Figure (4-B): Calculated predator prey ratios in untreated cotton area (control) at Manzala district during 2009 season.

Figures (5 A and B ) show the results of using predator $C$. undecimpunctata aiming to control the piercing-sucking insect in cotton during 2009 season.

It can be noted from this Figure that the predator prey ratio was exceeded 1:10 (the critical ratio) in the second week of June, in the first week of July, in the first week of August and the end of August. The numbers needed from the reared predator were two thousand in the four date's release, respectively. The results in this figure indicated that the weekly total number of piercing-sucking insects were lower than that in the untreated area, that is certain due to the effective role of the released beneficial insect in checking the piercing-sucking insects as long as ratio of their abundance was within the critical ratio $1: 10$ 
Ghanim, A. A. et al.

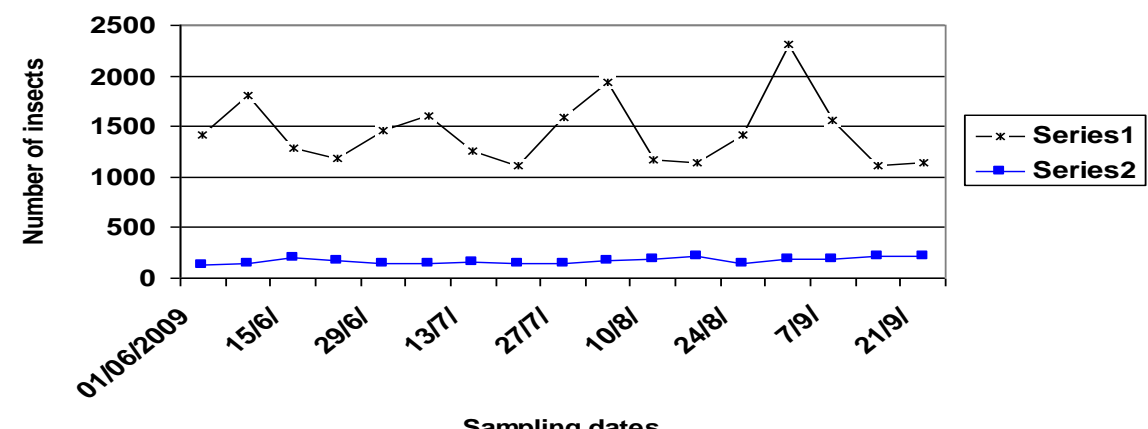

Figure (5-A): Weekly numbers of certain piercing-sucking insects and their associated predatory insects in treated cotton area with C. undecimpunctata at Manzala district during 2009 season.

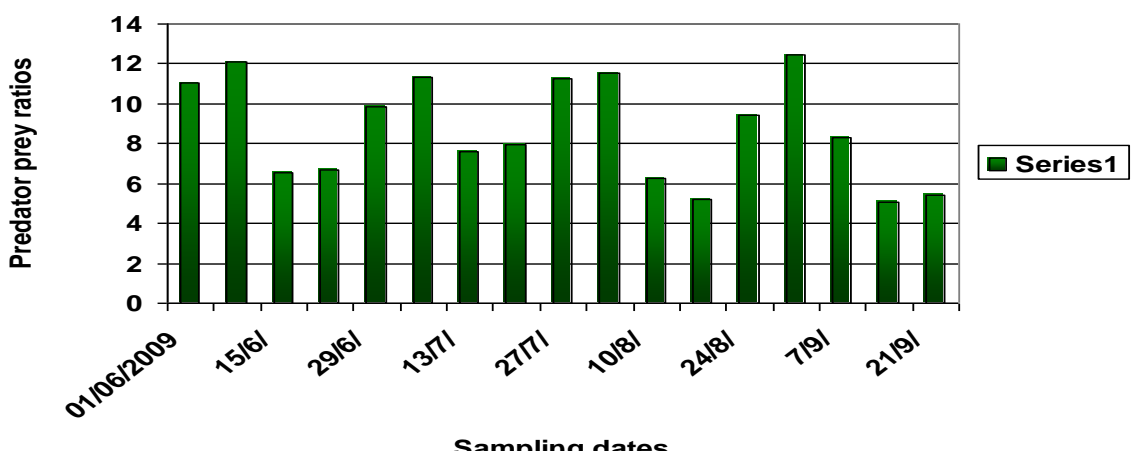

Figure (5-B): Calculated predator prey ratios in treated cotton area with $C$. undecimpunctata at Manzala district during 2009 season.

Figures (6 A and B) show the results of using insecticides aiming to control the injurious insect in cotton during 2009 season.

It can be noted from this Figure that the predator prey ratio was exceeded 1:10 (the critical ratio) in the second week of June, in the first week of July, in the first week of August, in the end of August, and in the second week of September. Also it can be noted from this Figure that the weekly total number of piercing-sucking insects was lower than that in the untreated area, that is certain due to the effective role of the insecticides in checking the piercing-sucking insects as long as ratio of their abundance was within the critical ratio $1: 10$.

These results was found to be closely match with those of Hamalainen (1977) who indicated that there was significantly negative relationship between P:p ratio of Coccinella septempunctata $L$. and aphid indices and added that a $50 \%$ decrease in the aphid, R. padi index describing the aphid population level is achieved when the initial $P: p$ ratio is at least 1:5. 


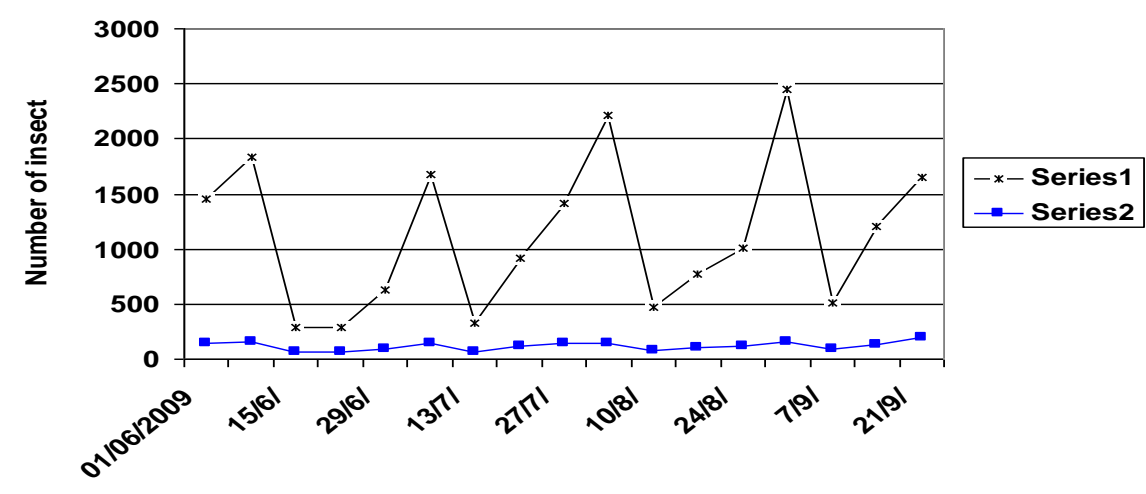

Sampling dates

Figure (6-A): Weekly numbers of certain piercing-sucking insects and their associated predatory insects in treated cotton area with insecticides at Manzala district during 2009 season.

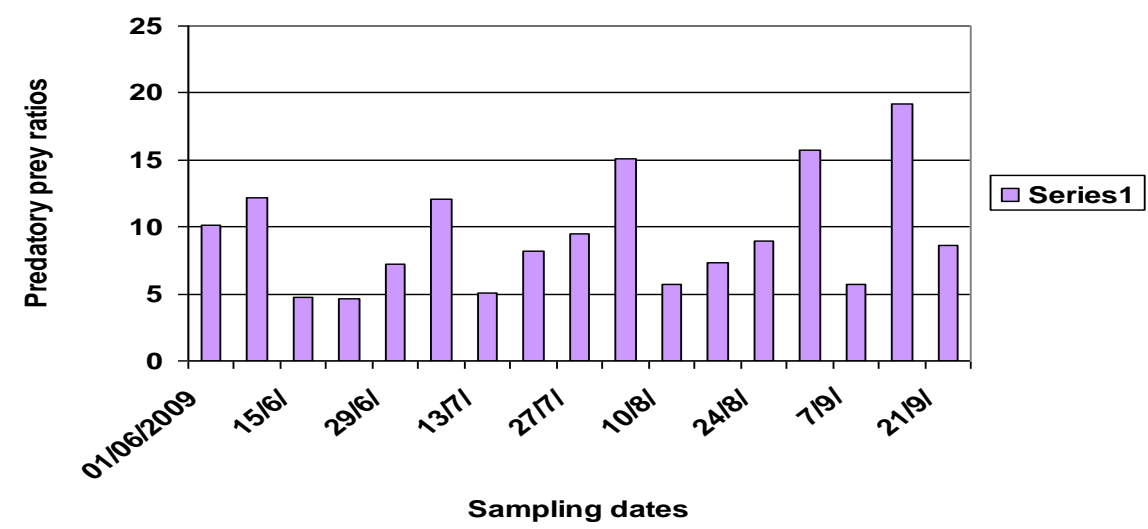

Figure (6-B): Calculated predator prey ratios in treated cotton area with insecticides at Manzala district during 2009 season.

El-Habi et al. (1999) in Morocco, evaluated the efficiency of $C$. septempuntata in controlling $A$. gossypii population on cucumber. This efficiency was function of the predator: prey ratio and the initial aphid density at the time of release of the predator: prey density had a large influence on the fecundity and establishment of this coccinellid. Also, they found that, the best control of aphid population was achieved using the lower predator prey ratios 1:5 and 1:10 after five days from adults release. Zaki et al. (1999) in Egypt reported that a single release of $C$. undecimpunctata (1:50 predator: aphids) resulted in $99.97 \%$ reduction of $A$. gossypii in an open field under green house. Al-Eryan et al. (2001) in Egypt indicated that results of releasing C. undecimpunctata against $A$. gossypii at predator: prey ratio 1:100, 1:50 and 1:25 resulted in reduction of aphid population by about 99.6, 99.4, 99.4 $\%$ respectively, within 28 days. Our results generally are in agreement with 
the findings of the work of Abdel-Naby (2003) in Egypt who found that the cotton aphid numbers decreased by 96.7 and $77.5 \%$ at $1: 15$ and 1: $30 \mathrm{P}: \mathrm{p}$ ratios, respectively when adults of $C$. undecimpunctata released. The number of aphids remained zero for a period of 13 days after the release. AbdelSalam et al. (2005) stated that effective control of $A$. gossipii was gained after one day from introducing the larvae of $C$. undecimpunctata when the P:p ratio was $1: 15$ or $1: 30$ meanwhile, at higher ratios $1: 60$ and 1:75 the aphid numbers decreased after seven days from the release. Liu and Stansly (2005) indicated that the coccinellid, Nephaspis oculatus (Blatchley) suppressed $B$. argentifolii populations when released one day after whitefly introduction in large cages at ratios of 1:4 and 1:20 beetle :whitefly. When beetles were released seven days after the whitefly infestation, significant pest reduction were obtained with the 1:4 beetle: whitefly ratio but not the 1:20 ratio. In clear cup cages on sweet potato leaves, significant suppression was obtained at beetle:whitefly ratios of 1:6.7, 1:10 and 1:20 when N. ocultus was released one day after the whitefly infestation. Saleh (2005) reported that a compete control of cowpea aphis Aphis carccivora was achieved after five days from release of $C$. undecimpunctata adults under cages with predator: prey ratios of 1:5 and 1:10.

\section{REFERENCES}

Abdel-Naby, A. R. 2003. Studies on natural enemies of some insect pests infesting tomatoes. M. Sc. Thesis, Fac. of Agric. Mansoura Univ.

Abdel-Salam, A. H. 1995. The biotic factors: evaluation of their performance under natural conditions in cotton plantation. Ph. D. Thesis, Fac. Agric., Mansoura Univ., $175 \mathrm{pp}$.

Abdel-Salam, A. H. ; Ragab, M. E.: El-Batran,L. A. and Ahmed A. R. 2005. Release of Coccinella undecimpunctata L. and Chrysoperla carnea (Steph.) as a biological control tool of the cotton aphid, Aphis gossypii Glover on tomato plants under field cage conditions. J. Agric. Sci. , Mansoura Univ., 30 (1) : 655-669.

Al-Eryan, M. A. S.; Zaitoon, A. A. and Rezk, H. A. 2001. The use of Coccinella 11-punctata (coleoptera: Coccinellidae)against Aphis gossypii (Homoptera: Apididae) on Okra plant. Alex. J. Agri. Res., 46: 107-114.

El-Habi, M. ; El-Jadd, L. Sekkat, A. and Boumezzough, A. 1999. Control of Aphis gossypii Glover (Homoptera: Aphididae) on cucumber under glass house by Coccinella septempunctata Lineaus (Coleoptera: Coccinellidae) Ins. Sci. and Its Application, 9(1): 57-63.

Eraky, S. A. and Nasser, M. A. K. 1993. Effect of constant temperatures on the development and predation prey efficiency of the ladybird beetle, Coccinella undecimpunctata L. (Coleoptera: Coccinellidae). Assiut J. Agric. Sci., 24: 223-231. 
Ghanim, A. A. and El-Adl, M. A. 1987. The role of Coccinella undecimpunctata $\mathrm{L}$. in suppressing the population level of Schizaphis graminum Rond and increase the yield in wheat plantation at Dakahlia Governorate, Egypt. J. Agric. Sci. Mansoura Univ., 12: 965-974.

Hamalainen, M. 1977. Control of aphids on sweet peppers, Chrysanthemums and roses in small greenhouses using the ladybeetles Coccinella septempunctata and Adalia bipunctata (Col., Coccinellidae). Ann. Agric. Fenn., 16: 117-131.

Hodek, I. ; Hagen, K. S. and van Emden, H. F. 1972. Methods for studing the effectiveness of natural enemies, pp. 147-188. In van Emden. H. F. (ed), Aphid technology. Academic, New York.

Liu, T.X. and Stansly, P. A. 2005. Timing and release rates for control of Bemisia tabaci (Homoptera: Aleyrodidae) by Nephaspis oculatus (Coleoptera: Coccinellidae) under confined conditions. Journal of Entomological Science, 40: 74-79.'

Mohamed, Nadia, E. A. A. Ghanim and A. H. Abdel-Salam, 2008. Estimation of release of Coccinella undecimpunctata $\mathrm{L}$. and Chrysoperla carnea (Steph.) for controlling the silverleaf whitefly, Bemisia argentifolii Bellows and Perring on squash plants under semifield conditions . Egypt. J. Appl. Sci., 23 (9): $359-372$.

Ragab, M. E. ; Abdel-Salam, A. H. and Abdel-Baky. N. F. 2002. Effect of some tomato varieties on the relative occurrence and population densities of predators and parasitoids associated with Bemisia spp. and Aphis gossypii. J. Union Arab. Biol., 17 (A) : 2903-312.

Rosenheim, J. A. ; Kaya, H. K. ; Ehler, L. E. ; Marios, J. J. and Jaffee, B. A. 1995. Intraguild predation among biological control agents: theory and evidence. Biol. Control, 5: 303-335.

Saleh, Fatma, M. F. 2005. Biological studies of certain predatory insects at Mansoura district. M. Sc. Thesis, Fac. Agric., Mansoura Univ., 149.

Shands, W. A. ; Simpson, G. W. and Gordon, C. C. 1972. Insect predators for controlling aphids in potatoes. 5 Numbers of eggs and schedules for introducing them in large field cages. J. Econ. Entomol., $65: 810-817$.

Symondson, W. O. C.; Sunderland, K. D. and Greenstone, M. H. 2002. Can generalist predators be effective biocontrol agenst ? Annu. Rev. Entomol., 47: 561-594.

Wetzel, T.; Ghanim, A. A. ; Freier, B. 1981. Zur Bedeutung von Predatoren und Parasiten fur die Uberwachung und Bekampfung von Blattlausen in Getreidebestanden. Nachrichtenblatt fur den Pflanzenschutz in der DDR, 35(12): 239-244.

Zaki, F. N. ; El-Shaarawy, M. F. and Farag, N. A. 1999. Release of two predators and two parasitoids to control aphids and whiteflies. Anzeiger fur Schadlingskunde, $72: 19-20$. 
Ghanim, A. A. et al.

تقييم اطلاق ابو العيد احد عشر نقطة لمكافحة بعض الحشرات الثاقبة الماصة التي تصيب حقول القطن في منطقة المنزلة ـ ـ محافظة الدقهلية.

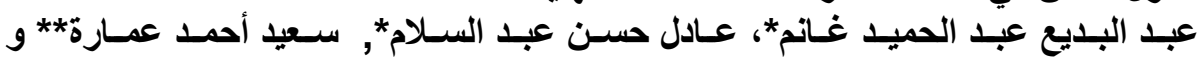
رضا محمد الفاتح رضوان الاندان

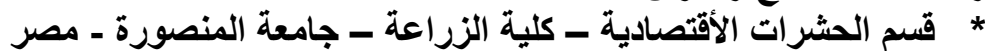

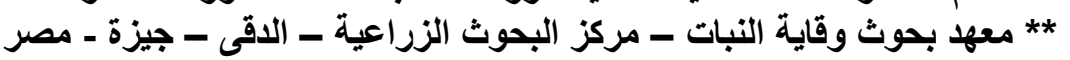

أجريت تجارب حقلية في حقول القطن في منطقة المنزلة ـ محافظة الدقهلية خلال موسمين

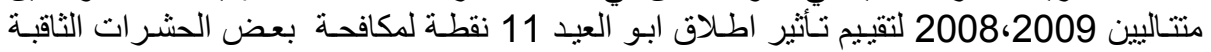

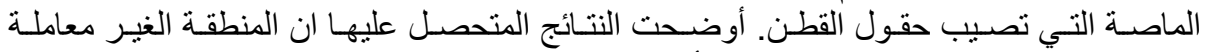

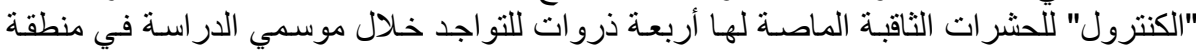

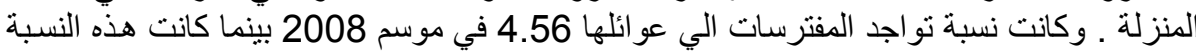

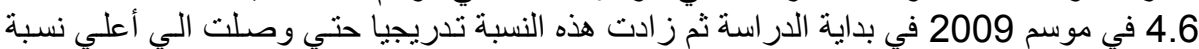

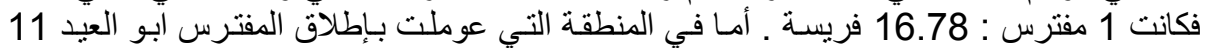

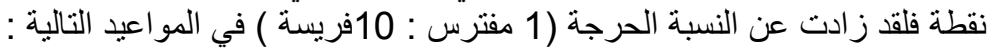

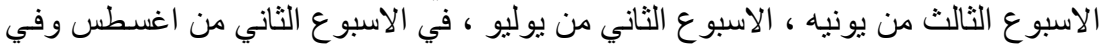

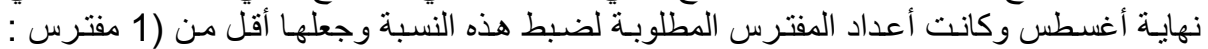

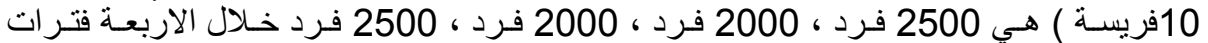

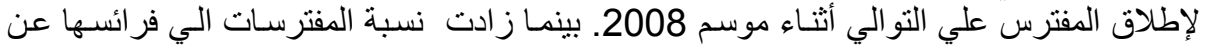

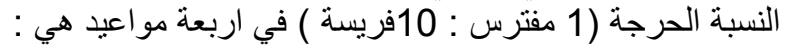

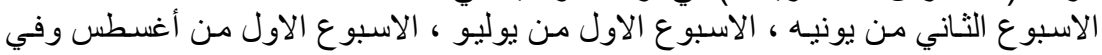

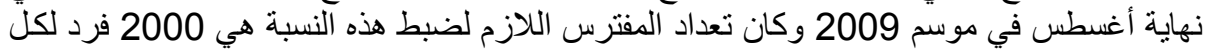

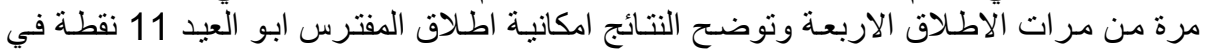
حقول القطن لمكافحة الحشرات الثاقبة الماصة كعنصر من عناصر المكافحة الحيوية.

كلية الزراعة - جامعة المنصورة

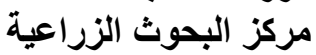

قام بتحكيم البحث إنم المث

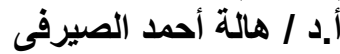
أ.د / أد / محمود السيد النجار المير 